\title{
Experimental-Phonetic Analysis of the Phonetic Structure of Word
}

\author{
Kifayat Alirzayeva ${ }^{1}$, Mehriban Ibadullayeva ${ }^{1} \&$ Gulnara Safarova ${ }^{1}$ \\ ${ }^{1}$ Department of English Phonetics, Azerbaijan University of Languages, Baku, Azerbaijan \\ Correspondence: Mehriban Ibadullayeva, Department of English Phonetics, Azerbaijan University of Languages, \\ 134, Rashid Behbudov str, AZ 1014, Baku, Azerbaijan. Tel: 994-50-674-6938. E-mail: \\ mehriban2002@yahoo.co.uk
}

\author{
Received: April 13, 2015 Accepted: May 4, 2015 Online Published: July 30, 2015 \\ doi:10.5539/ijel.v5n4p120 URL: http://dx.doi.org/10.5539/ijel.v5n4p120
}

\begin{abstract}
The article has been written on the basis of comparative-typological and experimental-phonetic methods in the study of the English and Azerbaijani languages belonging to different language systems (English belonging to analytical type of languages, Azerbaijani to the synthetic type of languages). The main aim of the investigation is to find out similarities and differentiations between (due to the acoustic parameters) phonetic structure of word in the monosyllabic and polysyllabic words in the English and the Azerbaijani languages. The analysis is based on experimental phonetic investigation. For the experiment PRAAT computer program has been used.
\end{abstract}

Keywords: word structure, monosyllabic, polysyllabic, acoustic, parameters

\section{Introduction}

In the modern linguistics investigation by the experimental-phonetic method is of peculiar importance. When we say the experimental phonetic method, we mean investigation of the topic in both phonetic and phonematic aspects. Different distinguished linguists have pointed out special importance of experimental phonetic investigation. Prof. Sherba in this respect noted: "In some parts of linguistics, lexicography, syntax and stylistics it is impossible to carry out investigation without experiment".

Grounding on this principle some other linguists have made necessary notes on the importance of experiments. One of them is prof. Veysally. In his works he also mentioned on the importance of experiments. As to him while carrying out experiments it is obviously seen how oscillograms and spectrograms change from sound to sound depending on their position in the speech chain.

Our aim is relying on these principles, the principle of importance of the experimental study, to carry out experimental phonetic analysis of the structure of the word in both English and Azerbaijani languages. We have focused our attention to the study of stress and melodic differentiations, the reasons why these differentiations occur in the compared languages and find out common and specific features taking place in both languages.

\section{Scope of the Study}

Experimental-phonetic methods play main role in Modern Linguistics. Without any hesitation it can be referred both to the phonetic and phonematic aspects. Different from the observation, an investigator plays an active role in the experiment, takes the investigated object within a definite condition and on the basis he/she investigates the relations between the phenomena and the situation that interests him/her. The special importance of experimental phonetic investigation has been noted by Sherba too: "It's impossible to do anything without experiments in some branches of linguistics. (Lexicography, Syntax and Stylistics)" (Scherba, 1979). The main privilege of experiment, as Sherba has noted, is that it gives opportunity to get "negative" information, namely the material which is impossible to get in Linguistics. To understand the experiment correctly we can say that it is realized in two ways in Phonetics: by listening and by means of special apparatus. The 1st is mostly called subjective method but the 2nd one-objective. The importance of the use of the objective methods in the linguistic investigations is explained by Sherba in this way: "Even the most trained ear can hear not all that exist, but the one which it has accustomed (Sherba, 1979).

According to Veysally's decision the investigation of every phonetic material can be useful only in the case when it is based on more experiment than on observation.

Oscillographic analysis requires hard work. In his investigations Veysally who has worked with oscillograms and 
specktograms writes: The most difficult case in the spectographic and oscillographic analysis is the segmentation of the speaking act, because there doesn't exist constant curves for any sound. Though the accuracy of the investigation results depends on the definite bordering of the sounds indirectly as we differ one phoneme from the others while we define the borders, and in this way we define the estimation of the parameter marks. Oscillograms and spectograms depending on their position in the speech chain change from a sound to a sound, from a speaker to a speaker.

We'd like to mention that stress is a very complicated phonetic phenomenon and it is closely connected with inner laws of a language. "The occurrence of the main tone frequency and regular change of intensity within the syllable is the specific feature of syllabic languages." (Zinder, 1979). Stress combines the sounds containing the sound combination of the word, if a word consists of more than one syllable in this case the stressed syllable turns it into a whole, the stressed syllable as if prevails over unstressed syllables (Zinder, 1979). The main function of the word stress is the formation of the general phonetic basis of the word. Sherba writes "In the idea, if it can be said like this, the stressed syllable is the strongest, the highest and the longest one." In the English language stress is free, that's it may fall on any syllable in different words. In disyllabic and polysyllabic words the distinction of one syllable from the other from the point of articulation is called word stress. Stress has got a very strong centralizing function in the English language. English stress is dynamic and intensity component has a privilege. The clear expression of the secondary stress in polysyllabic words is one of the main peculiarities of the English language.

Basically the main stress in English falls on the 2nd or on the 3rd syllables at the end of the polysyllabic words but the secondary stress falls on the 1st and 2nd syllables from the beginning.

\section{Research Methodology}

We have used in this article comparative typological and experimental-acoustic methods in the investigation of phonetic structure of words, in the monosyllabic and polysyllabic words in the English and Azerbaijani languages.

\section{Experimental Phonetic Analysis of Phonetic Structure of Word}

In Modern English the use of the experimental acoustic method of analysis of prosodic phenomena (intensity, length, tone etc.) gives an opportunity to express objective thoughts on the main features of stress and also to determine its peculiarities visually. That's why the use of the experimental investigation method is of great importance in learning and teaching languages. In linguistic sources it is noted that, the melody among the other acoustic parameters has got a leading role (Zinder, 1979). Melody is explained by Zinder in this way: "Melody serves to define the communicative types of sentences—-statements, questions, e.t.c. more than other components of Intonation. To Veysally: "In the speech act the rise and fall of the tone contain its melody. As the gained results at the end of the investigation depend on the estimation of the tone, this process requires special attention. It's also necessary to underline that the fundamental frequency analysis of tone is very difficult, because it carries very much information, which is impossible to be gained by words. In the following English words as "gardenparty", "characterizing" and "gas-mask" the maximum tone frequency is observed in the 1st syllables. In

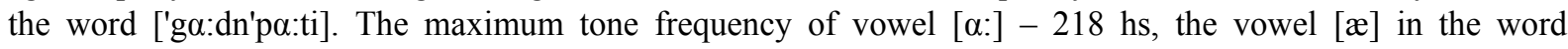
['kærrktəraIzIy] - $202 \mathrm{hs,} \mathrm{of} \mathrm{the} \mathrm{vowel} \mathrm{[æ]} \mathrm{in} \mathrm{the} \mathrm{word} \mathrm{['gæsma:sk]} \mathrm{-} 230 \mathrm{hs}$ is noted in the quantity. The main tone frequency results of the primary and secondary stressed syllables of the English words [In'finitiv],

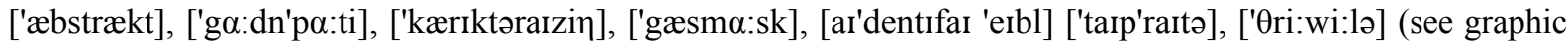
1)

The maximum tone frequency of $315 \mathrm{hs}$ is observed in the initial syllable of the word "pack-animal" [pæk'ænıməl]. The interval difference between the maximum and minimum indexes of the tone frequency in the word is 66 hs. The same can be observed in the word "commonplace book" ['kbmənpleis buk]. The main tone frequency in the initial syllable of the word is $313 \mathrm{hs}$. The interval difference between the maximum and minimum indexes of the word tone frequency is $117 \mathrm{hs}$. In the word "widow woman" ['widou 'wu:mən]. The main tone frequency in the vowel [I] of the first syllable is $310 \mathrm{hs}$. The interval difference between the maximum and minimum indexes of the tone frequency within the word is $42 \mathrm{hs}$. 


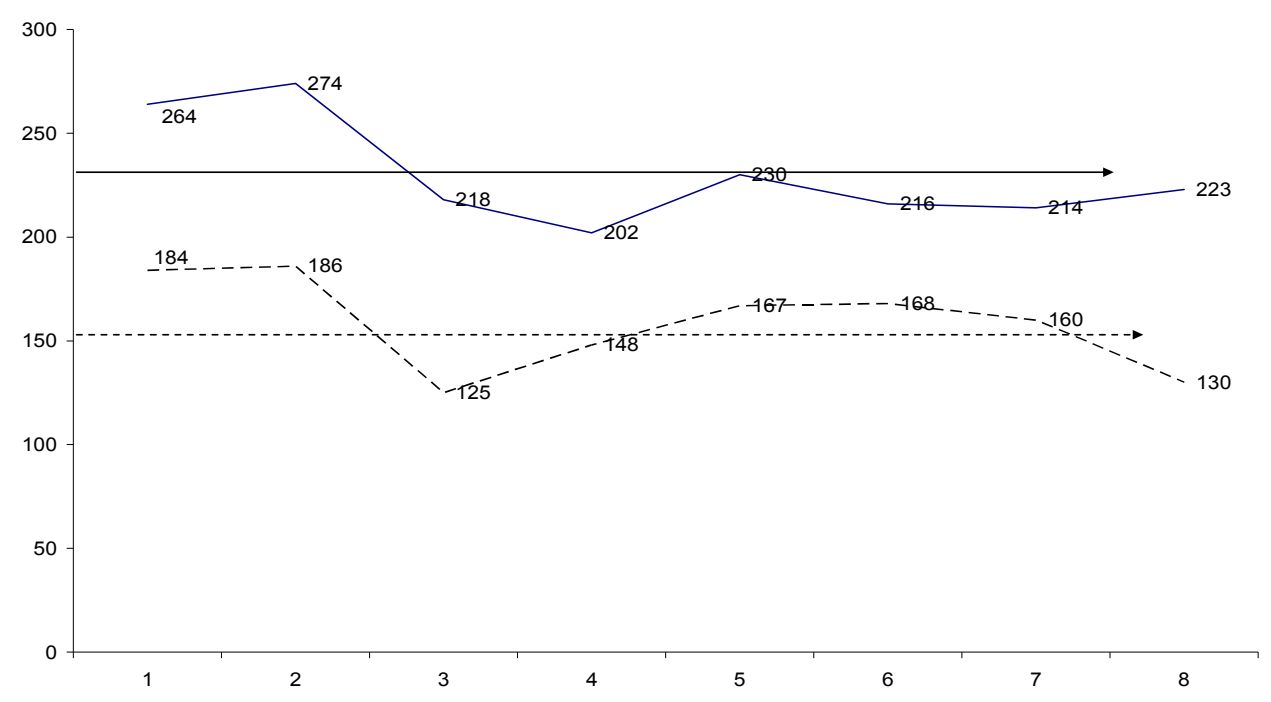

As primary stress falls on the prefixes in the words that are formed by adding consonants $[\mathrm{m} ; \mathrm{p} ; \mathrm{s} ; \mathrm{r}]$ in the superlative degree in the Azerbaijani language, maximum tone frequency also belongs to these syllables. In the compound nouns by combining 2 words in the Azerbaijani language the primary stress falls on the last syllable of the word and the stress of the 1st component, weakening a bit is converted to an additional stress. The gained experimental results completely confirm it. Primary stress in the Azerbaijani words "bağlamayacaqlar", "işləməyəcəklər", “döyüşdürməyəcəklər” "kəsməyəcəklər”, "bölüşdürməyəcəklər”, "duymayacaqlar", "unudulmayacaqlar", "vuruşdurmayacaqlar" "yarışdırmayacaqlar" falls on the last syllable of the root word and it can be observed in the tone frequency of the same syllable. The occelogramic analysis of the Azerbaijani words as "özünüqiymətləndirmə", "istiqamətləndirici", "adamayovuşmazlıq", "dənəcikmeyvəlilər" presents some interesting facts for the investigation. For example: In these words a weaker stress is observed on the last syllable of the 1 st component but primary stress is observed on the last syllable of the 2 nd component. The primary stress of the compound words formed by the combination of three words in the Azerbaijani language falls on the last syllable of the 3rd component by partially weakening of the stresses of the 1st and 2nd components are converted to the secondary stress. The maximum tone frequency in the English word "archbishopric" [ $\alpha: t$ 'brfəprrk] belongs to the vowel [I] - 252 hs. The oscillographic investigation of the words "discontinue" ['diskən'tinju:] shows the maximum tone frequency in the vowel [r] -220 hs. One of the main acoustic peculiarities distinguishing speech sounds from one another in the linguistic sources is considered to be intensity.

As Zinder notes: "Most of all the Intensity of the vowel completely depends on the speech intensity, as well as on the position of its relation to the word stress or sentence stress. The stressed vowel in the dynamic stress is more intensive than in the unstressed syllable or on the contrary" (Zinder, 1979). Besides, vowel intensity is connected with its acoustic quality. For example, closed vowels have generally a weaker intensity than open vowels. It means that the phoneme [a] will be more intensive than the phoneme $[\mathrm{I}]$ in the same phonetic position (Zinder, 1979).

Besides, Intensity doesn't always remain unchangeable in the vowel pronunciation. In major cases, the intensity movement in the vowels depends on different situations, on the position of the vowel affecting to the stress relation, and on the adjacent consonants and so on (Zinder, 1979).

Veysally also paid attention to the direct dependence of the voice intensity on the widening of the amplitudes: "The larger amplitude of the voice is, the more intensity of the voice". As the stress in the English word "infinitive" [In'finitiv] falls on the 2nd syllable the intensity peak is also noted in the same syllable $-79 \mathrm{db}$. The lowest index of the amplitudes in the word is noted on the last syllable $-73 \mathrm{db}$.

As the stress in the Azerbaijani words "yaya", "tələ", "səsə", "qaraqaş" and "dardar" falls on the 2nd syllable, intensity peak is also noted in them. According to the experimental results the vowel intensity of the main stressed syllables in the Azerbaijani words is rather higher than the vowel intensity in the additional stressed syllables. The maximum intensity in the English word "pack-animal" [pæk'ænıməl] is noted on the initial syllable. The interval difference between the maximum and minimum word indexes is $11 \mathrm{db}$. We can find the same situation in the English word "commonplace book" ['kbmənpless buk]. The intensity in the initial syllable 
is $91 \mathrm{db}$. The primary stress of the compound nouns formed by combining two words in the Azerbaijani language falls on the last syllable of the last word, but the stress of the 1st component converts into bit weakening additional stress. For example: the maximum intensity in the main stressed syllables of the Azerbaijani words "quzuqulağı", "əlüzyuyan”, “ağcaqanad", “tozsoran”, “əməksevər”, "dəvədabanı", "ağacdoğrayan”, "adətdənkənar", "giləmeyvə" and the English words "impartiality" ['Im,pa:fi'æliti] and impossibility [Im,pbsa'brliti] are $87 \mathrm{db}-89 \mathrm{db}$.

The intensity in the second stressed syllables is rather low $80 \mathrm{db}-82 \mathrm{db}$. The intensity indexes of the primary and secondary stressed syllable of the English words: infinitive [in'finıtıv], ['æbstrækt], ['ga:dn'pa:tı], ['kærrktəraızıy], ['gæsma:sk], [a1'dentıfa1 'eıbl], ['taıp'raıtə], ['Өri: 'wi:lə] are indicated in the table below.

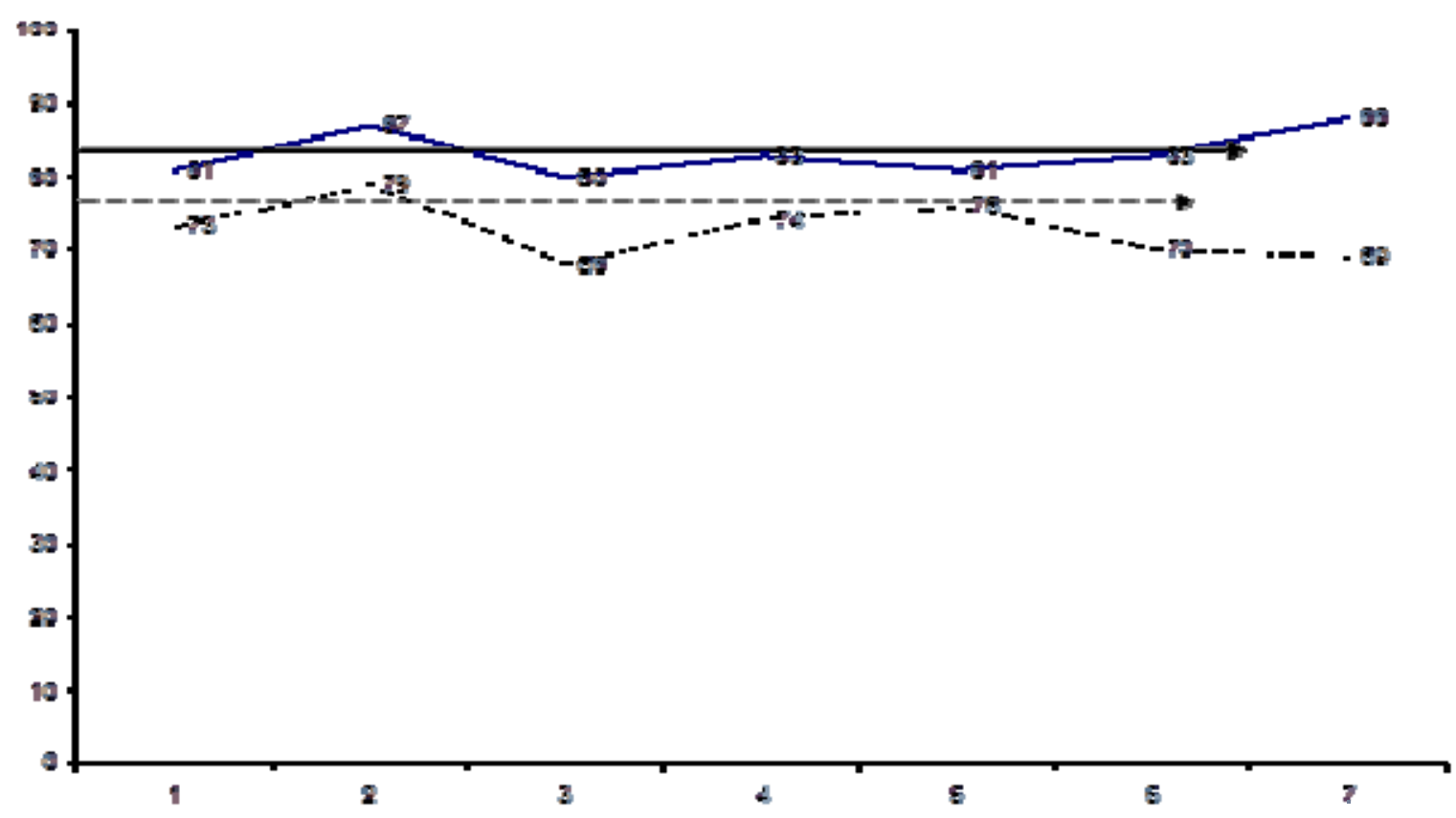

The Intensity in the primary stressed syllables of the English words "individuality" [,Indi,vidju'æliti] and "individualistic" [,Indı'vidjuəlıstrk] has found its reflection in the following indexes: $89 \mathrm{db}-90 \mathrm{db}$. The intensity in the secondary stressed syllables is rather low $81 \mathrm{db}-82 \mathrm{db}$. It should be mentioned that in the process of speech from the point of time, speech sounds have different lengths. Sherba considered the length (the duration spent on the sound pronunciation) as the main component of the word stress (Zinder, 1979). Just for this reason, the length parameter is more important than the intensity and main tone frequency in the phonetic characteristics of the speech sounds. Zinder writes about the length of the speech sounds: "The influence of speech tempo on the sound change is great. The sounds are certainly pronounced more clearly in the low tempo than the sounds in the high tempo" (Zinder, 1979).

Zinder writes "the length of the sound usually depends on the phonetic situations, exactly saying directly on the phonetic positions. Basically, the length of the sounds is different in the open and closed syllables: In the Azerbaijani words "yaya", "tələ", "səsə", "qaraqaş" and "dardar". The stress falls on the 2nd syllable and maximum of time spent on this articulation also appears in the same syllables as in the other parameters. As to the results of the experiment, time of articulation of vowel pronunciation in the main stressed syllables is more than the time of vowel pronunciation in the additional stressed syllables. In the Azerbaijani language the words "bağlamayacaqlar", "işləməyəcəklər", "döyüşdürməyəcəklər", "kəsməyəcəklər”, "bölüşdürməyə-cəklər", "duymayacaqlar", "unudulmayacaqlar", "vuruşdurmayacaqlar", "yarışdırmayacaqlar" which don’t accept stress on adding suffexes, maximum time spent in the pronunciation has been discovered on the final position of the word root.

It depends on the acoustic quality (occlusive or constructive, voiceless or voiced), the quality of the consonants followed by vowels, place of stress (stressed syllable, preceded the stress, followed the stress, the second) and so on, as well as on the number of the syllables in the words and word continuations. There is a definite dependence 
between the vowel length and its quality (Zinder, 1979).

As the stress falls on the 1st syllable in the English word "infinitive" [In'finitiv] the maximum spending of time on the pronunciation is noted in the syllable where $[\mathrm{I}], 113 \mathrm{~m} / \mathrm{sec}$. The minimum time spent on the time of pronunciation in the word in the last syllable is $86 \mathrm{~m} / \mathrm{sec}$. The difference between the maximum and minimum length within the word is $27 \mathrm{~m} / \mathrm{sec}$. / see oscillogram. Close to the end the reduction of the marks of the length is observed in the analyzed words. The oscillogramic analysis of the Azerbaijani words "özünüqiymətləndirmə", "istiqamətləndirici", "adamayovuşmazlıq", "dənəcikmeyvəlilər" presents some interesting facts connected with the time parameters. In above mentioned words a rather weak stress is noted in the last syllable of the 1st component, but the main stress in the last syllable of the 2nd component is observed. In the English words "Individuality [,Indı,vidju'æliti] and "individualistic" [,IndI'vidjuəlıstrk] the intensity in the main stressed syllable found its appropriate reflection in the following indexes: $89 \mathrm{db}-90 \mathrm{db}$. In the secondary stressed syllables the intensity is rather weak $81 \mathrm{db}-82 \mathrm{db}$. Time indexes of the main and secondary stressed syllable in the English words [In'finıtıv], ['æbstrækt], ['ga:dn'pa:ti], ['kærrktərarrı]], ['gæsma:sk], [ar'dentıtar 'erbl], ['tarp'rartə], ['Өriwi:lə]: See the table below:

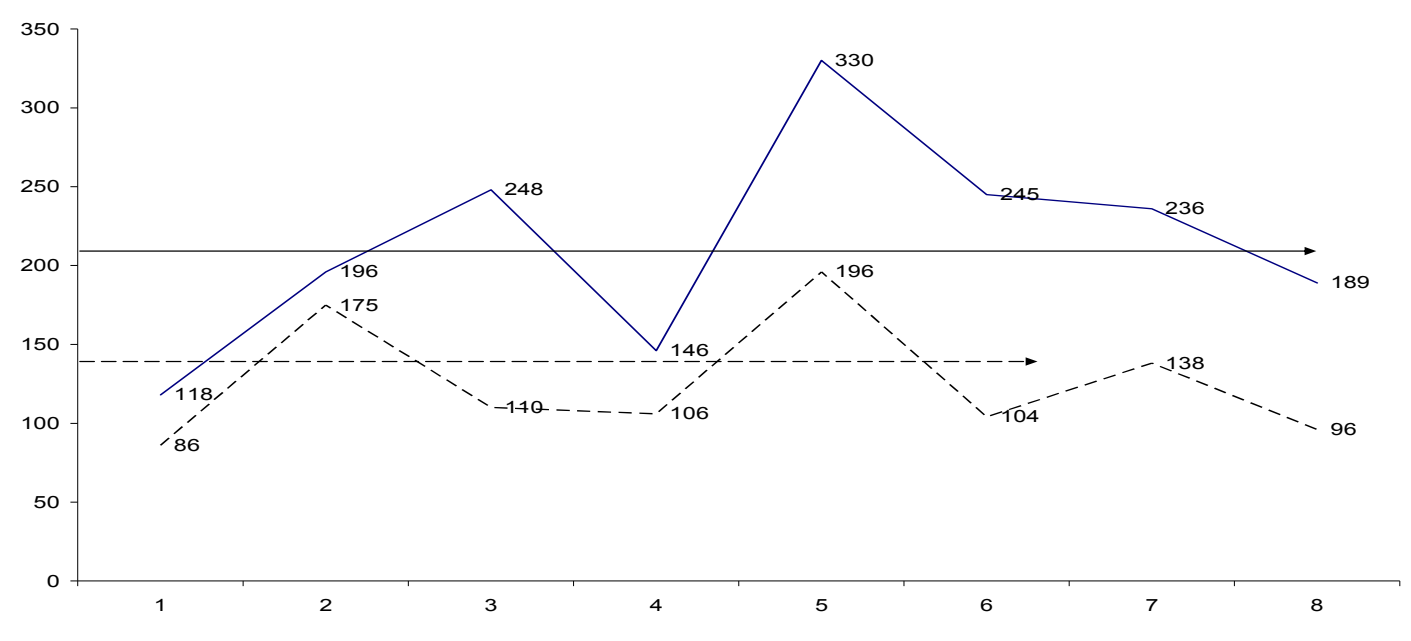

In the both languages whenever the number of syllables increases in the words, the time spent on their pronunciation reduces. To put in other words the number of the syllables of the words with their pronunciation time is improportional. Zinder also noted: "the length depends on the phonetic position as well as on the number of the syllables in the word" (Zinder, 1979).

\section{Conclusion}

Experimental - acoustic analysis of the materials of the compared English and Azerbaijani languages helps us to come to the following conclusions:

1) One of the main factors that influences on the length of syllables in the compared English and Azerbaijani languages is the number of the syllables in the word. That's whenever the number of the syllables in the word increases the time length spent on the pronunciation reduces. The medium pronunciation speed of the syllables in the Azerbaijani words "əmənköməncişəkillilər", "əmənkömənçiçəklilər", "dəmirağaçşəkillilər" is $75 \mathrm{~m} / \mathrm{sec}$., 69 $\mathrm{m} / \mathrm{sec}$., $87 \mathrm{~m} / \mathrm{sec}$. The medium pronunciation speed in the abbreviations "ATӘT", "AXCP", "SITA", "AȘPA", "NATO" is $160 \mathrm{~m} / \mathrm{sec} ., 129 \mathrm{~m} / \mathrm{sec}$., $146 \mathrm{~m} / \mathrm{sec}$., $150 \mathrm{~m} / \mathrm{sec}$., $151 \mathrm{~m} / \mathrm{sec}$. Medium pronunciation tempo in the English words ['soudə'wo:tə'bbtl] is $107 \mathrm{~m} / \mathrm{sec}$., in the word [wofhænd'bersn] is $112 \mathrm{~m} / \mathrm{sec}$., in the word [wp Shænd'stænd] is $105 \mathrm{~m} / \mathrm{sec}$., in the word ['werst'perpə'b a :skit] is $98 \mathrm{~m} / \mathrm{sec}$., in the word

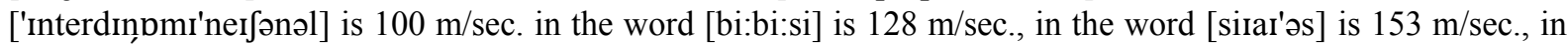
the word [nok] - is $183 \mathrm{~m} / \mathrm{sec}$, in the word [ju: əs'ai] is $182 \mathrm{~m} / \mathrm{sec}$.

2) Maximum time spending in the both compared languages belongs to the stressed syllables. In the English words [In'finitıv], ['æbstrækt] it is $264-184$ hs and 274-190 has. In the Azerbaijani words "yaya", "tələ", "səsə" it is 163: $172 \mathrm{hs}, 150 \mathrm{hs:} 158 \mathrm{hs,} 145: 152 \mathrm{hs}$. Maximum tone frequency in the independent stressed abbreviations in the English language is observed in the 2nd syllable /bi:bi:si/ - 214 hs-216 s. - 170 hs [sirar'əs] $196 \mathrm{hs}-230 \mathrm{hs}, 170 \mathrm{hs}$ [ju: ənəu] -214 hs. $-221 \mathrm{hs}-193 \mathrm{hs}$ and so on. Maximum tone frequency in the 
Azerbaijani words BMT, ATS, BDU, MDB, BBC, MSK is observed in the last syllable: 178-162-182 hs, 167-151-176 hs. $168-157-170$ hs, $168-170-179$ hs, $176-172-180$ hs, $176-163-181$ hs. and so on.

3) The time length spent on the main stressed syllable pronunciation in the both compared languages is more than the time parameter of the secondary stressed syllable. Both in the English and Azerbaijani languages the time spent on the pronunciation of the stressed syllables prevails over the time spent on the pronunciation of the unstressed and secondary stressed syllables.

4) Maximum tone frequency in the both languages is observed in the stressed syllables. The highest tone frequency in the English words [pæk'ænıməl] and ['hændıkæp] is observed in the stressed syllables: 315 hs: 250 hs. Tone frequency relativity between the main and additional stressed syllables in the Azerbaijani words "qapqara", "gömgöy", "ağappaq", "bapbalaca" is 192 hs - 173 hs, 190 hs-152 hs, 195 hs- 153 hs, 180 hs-156 hs.

5) Maximum tone frequency for the main stressed syllables in the English and Azerbaijani languages is typical: In the English word [Im,ppsibrliti] the high tone frequency in the [I] vowel of the main stressed syllable is 236 hs, but in the secondary stressed syllable is 219 hs./ In the words [,pn,əmætə'pi:ə], [pæælətəla'zərfn] [In, $\mathrm{d} \Lambda$ strialar'zəIIn] the high tone frequency in the main stressed syllables is expressed by the following indexes: 230 hs-210 hs, 240 hs-213 hs, 227 hs -204 hs, 216-199 hs. In the Azerbaijani words "quzuqulağı", "əlüzyuyan”, "ağcaqanad", "ağsaqqal" - the main frequency relativity of the main and additional stresses is $150 \mathrm{hs}-172 \mathrm{hs,}$ 158 hs- 193 hs, 172 hs-195 hs, 168 hs-186 hs. We'd like to underline that in the Azerbaijani language the main stress usually falls on the last syllable of the word and it is also observed in the acoustic indexes of the same syllable. But in the English language the main stress may fall on the initial and on the 2nd syllable from the end or on the 3rd syllable.

6) Maximum intensity indexes as well as the main tone fundamental frequency and length parameters are typical for the stressed syllables. For example: in the word [In'finitiv] - 73:79 db. In the word ['æbstrækt] 79:84 db. In the Azerbaijani words "yaya", "tələ", "səsə" this relativity is $74 \mathrm{db}: 78 \mathrm{db}, 72 \mathrm{db}: 74 \mathrm{db}, 70 \mathrm{db}: 73 \mathrm{db}$ and so on. In the English word [Im,ppsa'brliti] maximum intensity in the vowel [I] of the 3rd syllable is $85 \mathrm{db}$, but in the secondary stressed syllable it is $79 \mathrm{db}$. In the Azerbaijani words "quzuqulağı", "əlüzyuyan", "ağcaqanad", "ağsaqqal" the relativity of the intensity of the main and additional stresses: $84 \mathrm{db}-86 \mathrm{db}, 79 \mathrm{db}-86 \mathrm{db}, 84 \mathrm{db}$ $-90 \mathrm{db}, 81 \mathrm{db}-87 \mathrm{db}$.

\section{References}

Roach, P. (2009). English Phonetics and Phonology (4th ed.). Cambridge: Cambridge University Press.

Yadigar, F. (1993). Phonetics and Phonology issues. Baku: Maarif.

Yadigar, F. (2003). Introduction to German Linguistics. Baku: Tahsil.

Zinder, L. P. (1979). General Phonetics. Moscow: Visshaya Shkola.

Scherba, L. V. (1979). Language system and speech activity. Leningrad: Nauka

\section{Copyrights}

Copyright for this article is retained by the author(s), with first publication rights granted to the journal.

This is an open-access article distributed under the terms and conditions of the Creative Commons Attribution license (http://creativecommons.org/licenses/by/3.0/). 